
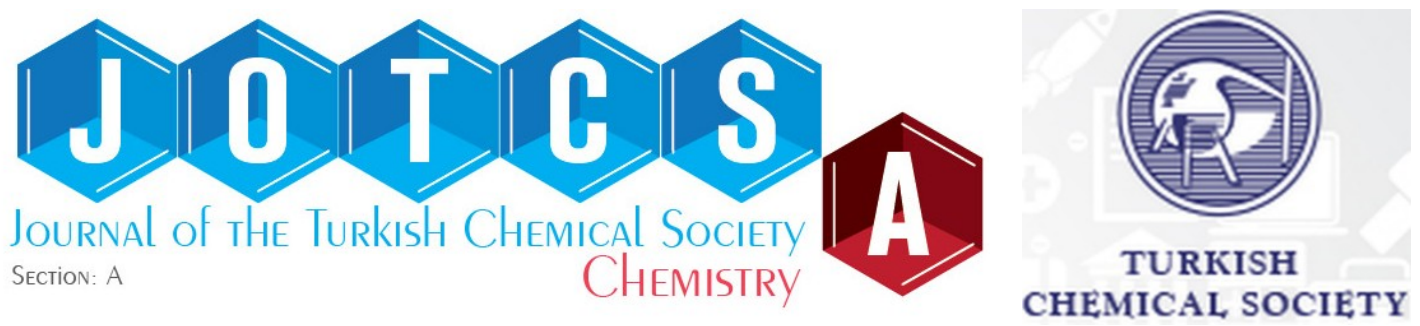

\title{
Photophysical properties of a newly synthesized unsymmetrically substituted zinc phthalocyanine
}

\author{
Ayfer Kalkan Burat $*$ iD, Hande Pekbelgin Karaoğlu* \\ Istanbul Technical University, Department of Chemistry, TR34469, İstanbul, Turkey.
}

\begin{abstract}
A novel unsymmetrically substituted zinc phthalocyanine (ZnPc) containing six hexylthio units and a morpholinoethoxy group was synthesized and characterized. Statistical condensation reaction of two different phthalonitriles was used for the preparation of unsymmetrical ZnPc. The novel compound was purified using chromatographic methods with the help of high solubility differences of phthalonitrile derivatives. Characterization of the compound was achieved by using NMR, FT-IR, UV-Vis, and mass spectroscopic methods. The photophysical measurements were made in tetrahydrofuran (THF). Fluorescent quantum yield $\left(\Phi_{F}\right)$ and fluorescence lifetime $\left(T_{F}\right)$ of unsymmetrical ZnPc were determined. Fluorescent quenching experiments were done by adding benzoquinone (BQ) in THF, and Stern-Volmer constant (Ksv) and quenching constant $\left(\mathrm{k}_{\mathrm{q}}\right)$ values were calculated.
\end{abstract}

Keywords: Fluorescence, phthalocyanine, quenching, unsymmetric, zinc.

Submitted: January 28, 2021. Accepted: April 30, 2021.

Cite this: Kalkan Burat A, Pekbelgin Karaoğlu H. Photophysical properties of a newly synthesized unsymmetrically substituted zinc phthalocyanine. JOTCSA. 2021;8(2):623-32.

DOI: https://doi.org/10.18596/jotcsa.870010.

*Corresponding author. E-mail: kalkanayf@itu.edu.tr, pekbelgin@itu.edu.tr

\section{INTRODUCTION}

Phthalocyanines (Pcs) can be functionalized for a variety of applications, from medicine to technology (1-5). They are also used as second-generation photosensitizers for the photodynamic therapy (PDT) of cancers and for inactivation of bacteria and viruses due to strong absorption in the red-visible region and high efficiency in producing reactive oxygen species $(6,7)$. The photochemical and physicochemical properties of Pcs can be altered by changing the substituents in the peripheral and nonperipheral positions or by inserting different metal ions in the central cavity $(8,9)$. Both peripherally and non-peripherally substituted Pcs have already been investigated as photosensitizers for PDT applications because the substituents affect the physicochemical properties of Pcs and the possibility of using them in vivo and in vitro studies $(10,11)$. Due to their unique photophysical and photochemical properties, Pc compounds can be applied in medical and industrial product development. For suitable applications, the design of phthalocyanines with desired properties can be accomplished by varying the central metal atoms and the substituents of Pc molecules. The most important problem encountered in the application of unsubstituted Pc is its low solubility in common organic solvents and in water. To improve the solubility of the Pc compound, long alkyne chains or bulky groups can be attached at the peripheral or non-peripheral positions of the macrocycle $(8,9,12$, 13).

Synthesis of Pcs for medical purposes is an important subject of research because it is preferred that the designed molecules do not show aggregation and have a lipophilic-hydrophilic balance. Aggregation of Pcs can be also prevented by peripheral, non-peripheral, or axial substitution of different groups $(12,13)$. One of these groups is morpholine (1,4-tetrahydro-oxazine), of great industrial importance and a wide range of applications. Morpholine and its derivatives are used as solvents, corrosion inhibitors, rubber additives, antioxidants, as well as in the production of drugs 
and herbicides. Morpholine derivatives are also of interest as they show biological activities such as anti-inflammatory, analgesic, antidepressant, and antitumor (14-17).

It has been found that the substitution of morpholine groups into the Pc structure modulates the physicochemical properties and amphiphilic nature of Pcs, thereby facilitating their potential applications in biology and medicine (18). Recently, zinc phthalocyanines conjugated with biotinylated graphene quantum dots (GQDs) have been synthesized by Nyokong et al., and their photophysicochemical properties, and in vitro photodynamic activities have been studied. It was reported that cationic $\mathrm{ZnPc}$ conjugated with the biotin functionalized GQDs exhibited a relatively better performance (19). In another study published in 2019, tetra-substituted Pcs and their cationic derivatives with morpholine groups at the peripheral and non-peripheral positions were synthesized, and their photodynamic antimicrobial chemotherapy activities were examined, and it was determined that cationic Pcs showed better photodynamic antimicrobial activity (20). In 2017, nonperipherally octasubstituted magnesium $\mathrm{Pc}(\mathrm{MgPc})$, and its cationic derivative carrying N-methyl morpholiniumethoxy groups were synthesized, and their photocytotoxicity against bacteria, fungi, and cancer cells were investigated. This work showed that quarternized $\mathrm{MgPc}$ has excellent photodynamic activity against planktonic cells of both Gramnegative and Gram-positive bacteria (21). These studies show that morpholine groups positively change the biological activity of Pcs (22). In addition, axially morpholine-disubstituted silicon phthalocyanines exhibited better antifungal photodynamic activity and DNA/BSA binding (2325).

Symmetrical and unsymmetrical morpholine substituted Pcs, synthesis, and investigation of their electrochemical and physicochemical properties were carried out by our group in previous years (26, $27)$. In addition, the symmetric octasubstituted Pcs derivative containing hexylthio groups was synthesized beforehand in the literature, and its photophysical and thermal properties were investigated (12). Here, we studied the synthesis and characterization of a novel unsymmetrically substituted zinc phthalocyanine ( $\mathrm{ZnPc}$ ) containing six hexylthio units and a morpholinoethoxy group at peripheral positions. The photophysical properties of this new compound were investigated by fluorescence measurements and compared with its octakis hexylthio substituted derivative in the literature (12). Hexylthio group was chosen for the electron donor property of the sulfur atom and its effect on the electronic properties of Pcs was investigated. In addition, morpholine groups also improve the biological properties of PCS (18-22). Therefore, in the study the effect of the combination of morpholine group with hexylthio groups, which shifts the $\mathrm{Q}$ band absorption to the red, on the photophysical properties of phthalocyanine was also investigated.

\section{EXPERIMENTAL SECTION}

\section{Materials and apparatus}

An Agilent VNMRS $500 \mathrm{MHz}$ spectrometer was used to determine the ${ }^{1} \mathrm{H}-\mathrm{NMR}$ spectrum of the synthesized complex. The FT-IR spectrum of the complex was recorded by using a Perkin-Elmer Spectrum One FT-IR UATR spectrometer. The UVVis spectrum of the compound was obtained using a Scinco LabProPlus UV/Vis spectrophotometer. Fluorescence spectra were obtained on Perkin-Elmer LS55 fluorescence spectrophotometer. Bruker Microflex LT MALDI-TOF MS spectrometer was used to record the mass spectrum.

4,5-bis(hexylthio)phthalonitrile (1) (28) and 4-(2morpholinoethoxy)phthalonitrile (2) (29) were synthesized as given in the literature. The chemicals and solvents used for the synthesis and purification of compounds $\mathbf{1}$ and $\mathbf{2}$ were also obtained from Sigma-Aldrich, Germany.

\section{Preparation}

Synthesis of 2,3,9,10,16,17-Hexakis(hexylthio)-23(2-morpholinoethoxy)) phthalocyaninatozinc(II) (3): $100 \mathrm{mg}(0.28 \mathrm{mmol})$ of compound $1,23.8 \mathrm{mg}(0.09$ mmol) compound $2,17.0 \mathrm{mg}(0.09 \mathrm{mmol})$ $\mathrm{Zn}\left(\mathrm{CH}_{3} \mathrm{COO}\right)_{2}$ and a catalytic amount of $1,8-$ diazabicyclo[5.4.0] undec-7-ene (DBU) were refluxed in dry $n$-hexanol under nitrogen $\left(\mathrm{N}_{2}\right)$ atmosphere for 24 hours. The mixture of reaction first cooled down to room temperature then precipitated by pouring it into ice-water, and the solid product was washed with methanol $(\mathrm{MeOH})$. Purification of the green compound was carried out by column chromatography on silica gel with dichloromethane (DCM): $\mathrm{MeOH}$ (25:1) and then with THF:n-hexane $(1: 1)$ as eluent. The compound was finally purified by thin layer chromatography using 25: 1 DCM: n-hexane mixture. Solubility: Soluble in dimethylformamide (DMF), DCM, dimethylsulfoxide (DMSO) and THF. $\mathrm{C}_{74} \mathrm{H}_{99} \mathrm{~N}_{9} \mathrm{O}_{2} \mathrm{~S}_{6} \mathrm{Zn}$ $(1404.41 \mathrm{~g} / \mathrm{mol})$ Yield: $21 \mathrm{mg},(16 \%)$. FT-IR $\left(U_{\max } / \mathrm{cm}^{-1}\right)$ : 3071 (Ar-C-H), 2953 (Aliph. -C-H), $1240(\mathrm{C}-\mathrm{N}), 1100(\mathrm{C}-\mathrm{O}-\mathrm{C})$. UV-Vis $\lambda_{\max }(\mathrm{nm}) \mathrm{THF}:$ 363, 699. ${ }^{1} \mathrm{H}-\mathrm{NMR}\left(500 \mathrm{MHz}, \mathrm{CDCl}_{3}\right): \delta$, ppm 7.63$7.52(6 \mathrm{H}, \mathrm{m}, \mathrm{Ar}-\mathrm{H}), 6.97(2 \mathrm{H}, \mathrm{s}, \mathrm{Ar}-\mathrm{H}), 6.61(1 \mathrm{H}, \mathrm{s}$, Ar-H), 4.74-4.69 (2H, brs, $\left.\mathrm{OCH}_{2}\right), 3.88-3.87(4 \mathrm{H}, \mathrm{t}$, $\mathrm{OCH}_{2}$, morpholine), $3.19\left(2 \mathrm{H}\right.$, brs, $\left.\mathrm{NCH}_{2}\right), 2.83(4 \mathrm{H}$, $\mathrm{t}, \mathrm{NCH}_{2}$, morpholine), 2.05-2.02 $\left(12 \mathrm{H}, \mathrm{t}, \mathrm{SCH}_{2}\right)$, 1.73-1.69 $\left(12 \mathrm{H}, \mathrm{m}, \mathrm{S}-\mathrm{C}-\mathrm{CH}_{2}\right), 1.50-1.42(36 \mathrm{H}, \mathrm{m}$, $\left.\mathrm{C}-\mathrm{C}-\mathrm{CH}_{2}\right), 1.01-0.92\left(18 \mathrm{H}, \mathrm{t}, \mathrm{CH}_{3}\right) .{ }^{13} \mathrm{C}-\mathrm{NMR}(500$ $\left.\mathrm{MHz}, \mathrm{CDCl}_{3}\right): \delta, \mathrm{ppm} 186.30,151.51,149.33$, $149.11,148.89,144.63,144.35,135.88,135.63$, $135.43,135.24,130.84,129.45,128.76,128.22$, $125.47,123.31,123.11,122.91,119.53,68.12$, $67.09,58.12,54.37,34.22,31.65,30.30,29.39$, 
22.66, 14.14. Anal. Calc. for $\mathrm{C}_{74} \mathrm{H}_{99} \mathrm{~N}_{9} \mathrm{O}_{2} \mathrm{~S}_{6} \mathrm{Zn}$ (1404.41 g/mol) \%: C, 63.29; H, 7.11; N, 8.98 Found: $\mathrm{C}, 63.65 ; \mathrm{H}, 7.34 ; \mathrm{N}, 8.61$. MS (MALDITOF): $\mathrm{m} / \mathrm{z} 1404.5 \mathrm{M}^{+}$.

\section{Photophysical parameters}

Fluorescence quantum yield and fluorescence lifetime:

The fluorescence quantum yield $\left(\Phi_{\mathrm{F}}\right)$ was determined by using a comparative method. The equation used in the comparative method is as follows, and $\mathrm{ZnPc}$ in DMF solution was used as standard. $\left(\Phi_{\mathrm{F}}=0.17\right)(30,31)$ :

$$
\Phi=\Phi_{F(S T D)} \frac{F A_{S t d} \eta^{2}}{F_{S t d} A \eta_{S t d}^{2}}
$$

In Eq. 1, $F$ and $F_{\text {Std }}$ denote areas under the fluorescent emission curves of compound $\mathbf{3}$ and its standard, respectively. The absorbances of standard solution and compound $\mathbf{3}$ are expressed as Astd and $A$, respectively. $n_{\text {std }}$ and $n$ indicate the refractive indices of solvents $\left(\mathrm{n}_{\mathrm{DMF}}=1.496, \mathrm{n}_{\mathrm{THF}}=1.4072\right)$.

Fluorescence lifetime $\left(T_{F}\right)$ indicates the meantime of the substance in the excited state prior to fluorescence and is calculated by the PhotochemCAD program using the Strickler-Berg equation. As an expected result of Eq. 2, the fluorescence quantum yield $\left(\Phi_{F}\right)$ and the fluorescence lifetime $\left(T_{F}\right)$ are directly proportional. In addition, the natural radiative lifetime ( $\left.T_{0}\right)$ was calculated using Eq. 2. $(30,31)$ :

$$
\Phi_{F}=\frac{\tau_{F}}{\tau_{0}}
$$

\section{Fluorescent quenching by 1,4-benzoquinone}

Fluorescent quenching experiments were done by adding the different concentrations of $\mathrm{BQ}$ solutions up to $0.040 \mathrm{M}$ to the fixed concentration solution of compound 3. As a result of fluorescent quenching experiments, an energy transfer took place between compound $\mathbf{3}$ and $\mathrm{BQ}$. Fluorescence spectra of compound $\mathbf{3}$ were recorded after each $\mathrm{BQ}$ addition. The change in the fluorescence spectra of compound 3 was evaluated to be consistent with the kinetic mechanism of the Stern-Volmer (SV) equation (Eq 3) (32):

$$
\frac{I_{0}}{I}=1+K_{S V}[B Q]
$$

$I_{0}$ is the fluorescence intensity of the fluorophore before the quencher is added, while $I$ is the fluorescence intensity in the presence of the quencher. The concentration of the quencher is represented by [BQ] and the Stern-Volmer constant by $K_{S V}$ found in the graph from [BQ] to $\mathrm{I}_{0} / \mathrm{I}$. The bimolecular quenching constant $\left(\mathrm{k}_{q}\right)$ is calculated from Eq. (4) (33):

$$
K_{S V}=k_{q} \times \tau_{F}
$$

\section{RESULT AND DISCUSSION}

\section{Synthesis and spectroscopic characterization}

Basically, three different methods are used for the synthesis of unsymmetrical Pcs. These are polymeric support method $(34,35)$, ring-expansion of sub-phthalocyanine (SubPc) (36, 37) and statistical condensation of phthalonitriles (two different phthalonitrile derivative, A and B) (38-40), respectively. In order to use the polymeric support method, the Pc must have a group that can be attached to the polymer. In the ring-expansion method, the SubPc is first synthesized in the $A_{3}$ structure, and then the ring expansion is made. Here, the statistical condensation method was used to prepare the $A_{3} B$ type unsymmetrical Pc. Pc derivatives containing mostly $A_{4}$ and $A_{3} B$ were synthesized as a result of cyclotetramerization of two different phthalonitrile compounds whose reactivities were close to each other. While the solubility of the phthalonitrile derivative (1) containing the hexylthio group is too high, the low solubility of compound $\mathbf{2}$ facilitated the isolation of the unsymmetric Pc. Targeted $A_{3} B$ Pc was isolated by sequential chromatographic purification methods.

Compound $\mathbf{1}$ and compound $\mathbf{2}$ were used as starting materials to obtain compound $\mathbf{3}$. Compound $\mathbf{1}$ was synthesized as a result of the base-catalyzed aromatic displacement reaction of hexanethiol with 4,5-dichlorophthalonitrile. The reaction was accomplished in dry DMF, with the addition of $\mathrm{K}_{2} \mathrm{CO}_{3}$ at $60{ }^{\circ} \mathrm{C}$ for $8 \mathrm{~h}$, and the product was purified by crystallization in $\mathrm{MeOH}$. Compound $\mathbf{2}$ was obtained, under conditions similar to the synthesis of compound $\mathbf{1}$, by the reaction of 4-nitro phthalonitrile with 2-morpholinoethanol. The reaction was completed at $50{ }^{\circ} \mathrm{C}$ for 72 hours using dry DMF and $\mathrm{K}_{2} \mathrm{CO}_{3}$ under nitrogen atmosphere. Column chromatography was used for the purification of the white product (silica gel, $1: 1$ chloroform $\left(\mathrm{CHCl}_{3}\right)$ :acetone). Cyclotetramerization of the phthalonitrile derivatives $\mathbf{1}$ and $\mathbf{2}$ with anhydrous $\mathrm{Zn}\left(\mathrm{CH}_{3} \mathrm{COO}\right)_{2}$ and $\mathrm{DBU}$ in $n$-hexanol at $160{ }^{\circ} \mathrm{C}$ over a 24 -hour period at an appropriate ratio led to the formation of the desired compound 3 (Scheme 1). A number of chromatographic methods were used to purify the raw product. 25: 1 DCM: $\mathrm{MeOH}$ followed by 1: 1 THF: hexane solution mixtures were used as the mobile phase in column chromatography. Finally, pure compound (3) was obtained by thin-layer chromatography using a 25 : 1 DCM: hexane mixture as eluent. Compound $\mathbf{3}$ dissolves in THF, DCM, DMSO, and DMF with a reaction yield of $16 \%$. 

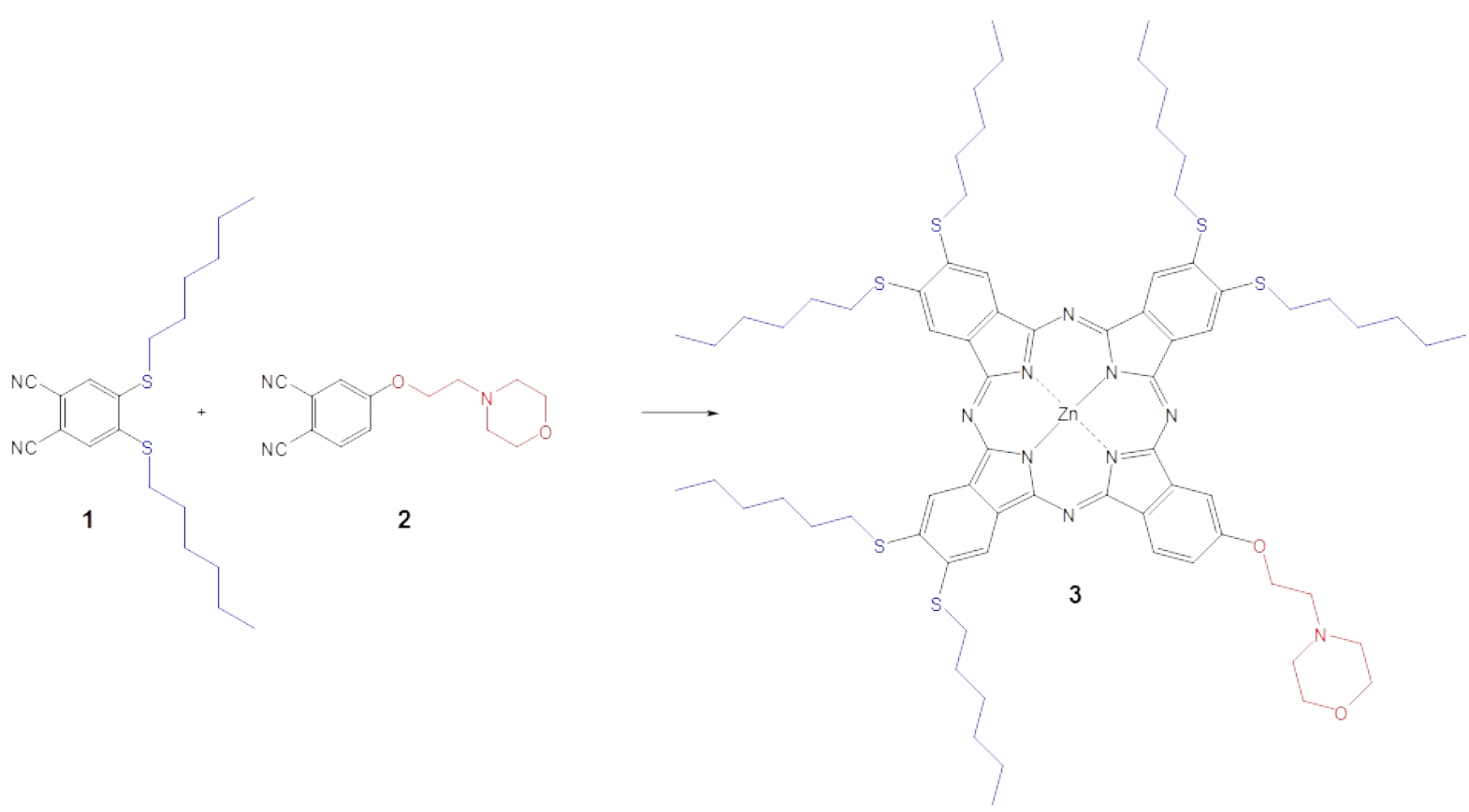

Scheme 1: Synthetic route to unsymmetric $\mathrm{ZnPc}(3): \mathrm{ZnCl}_{2}, \mathrm{DBU}, \mathrm{n}$-hexanol, $24 \mathrm{~h}$, reflux.

The novel unsymmetric Pc compound (3) was characterized by using NMR, FT-IR, UV-Vis and mass spectroscopic methods. In the FT-IR spectrum, aromatic and aliphatic $\mathrm{C}-\mathrm{H}$ vibrations were observed at $3071 \mathrm{~cm}^{-1}$ and $2953 \mathrm{~cm}^{-1}, \mathrm{C}-\mathrm{N}$ and C-O-C vibrations were observed at 1240 and $1100 \mathrm{~cm}^{-1}$, respectively. The ${ }^{1} \mathrm{H}$ NMR spectrum of 3 in $\mathrm{CDCl}_{3}$ indicated the Pc protons between 7.63-6.61 $\mathrm{ppm}$, the aliphatic protons of morpholine group at $4.74\left(\mathrm{O}-\mathrm{CH}_{2}\right), 3.88\left(\mathrm{O}-\mathrm{CH}_{2}\right), 3.19\left(\mathrm{~N}-\mathrm{CH}_{2}\right)$, and $2.83 \mathrm{ppm}\left(\mathrm{N}-\mathrm{CH}_{2}\right)$, respectively. The $\mathrm{SCH}_{2}, \mathrm{SCCH}_{2}$ and $\mathrm{CH}_{3}$ protons were observed at 2.05, 1.73-1.42, and $1.02 \mathrm{ppm}$, respectively. The ${ }^{13} \mathrm{C}$ NMR spectrum of $\mathbf{3}$ is compatible with the structure. While the carbons of the phthalocyanine ring were observed between 186-119 ppm, aliphatic carbons were detected between 68-14 ppm. The molecular ion peak observed at $\mathrm{m} / \mathrm{z}=1404.5[\mathrm{M}]^{+}$for compound 3 confirms the proposed structure.

The simplest Pc unit is the $18-\pi$ electron system giving electronic spectra with two absorption regions. These are the $B$ band in the UV region at about $300-400 \mathrm{~nm}$ and the $\mathrm{Q}$ band in the visible region ranging between 600-700 $\mathrm{nm}$, both correlating to $\pi-\pi *$ transitions. UV-Vis spectrum of $\mathbf{3}$ recorded in THF exhibits an intense single $Q$ band absorption at $699 \mathrm{~nm}$ and $B$ band at $363 \mathrm{~nm}$. The spectrum shows the typical pattern of metallophthalocyanine complexes $(29,30)$. When the electronic absorption spectrum of $\mathbf{3}$ is compared with its derivatives in the literature, the $\mathrm{Q}$ band of $\mathbf{3}$ was shifted to $5 \mathrm{~nm}$ blue according to octakis(hexylthio)-substituted $\mathrm{ZnPc}$ and $22 \mathrm{~nm}$ red according to tetrakis(morpholinoetoxy)-substituted ZnPc.

Upon excitation at $615 \mathrm{~nm}$, fluorescence measurements and fluorescent quenching tests of compound $\mathbf{3}$ were carried out in THF. The fluorescent emission, excitation, and absorption spectra of compound 3 are as in Figure 1 . The fluorescence emission of $\mathbf{3}$ was found to be at 719 $\mathrm{nm}$. The Stokes shift value calculated as $20 \mathrm{~nm}$ for compound $\mathbf{3}$ is consistent with the Stokes shift of Pcs calculated as $20-30 \mathrm{~nm}$ (41). The absorption and excitation spectra of $\mathbf{3}$ were similar and also observed as a mirror image of the fluorescent spectrum $(30,31)$. 


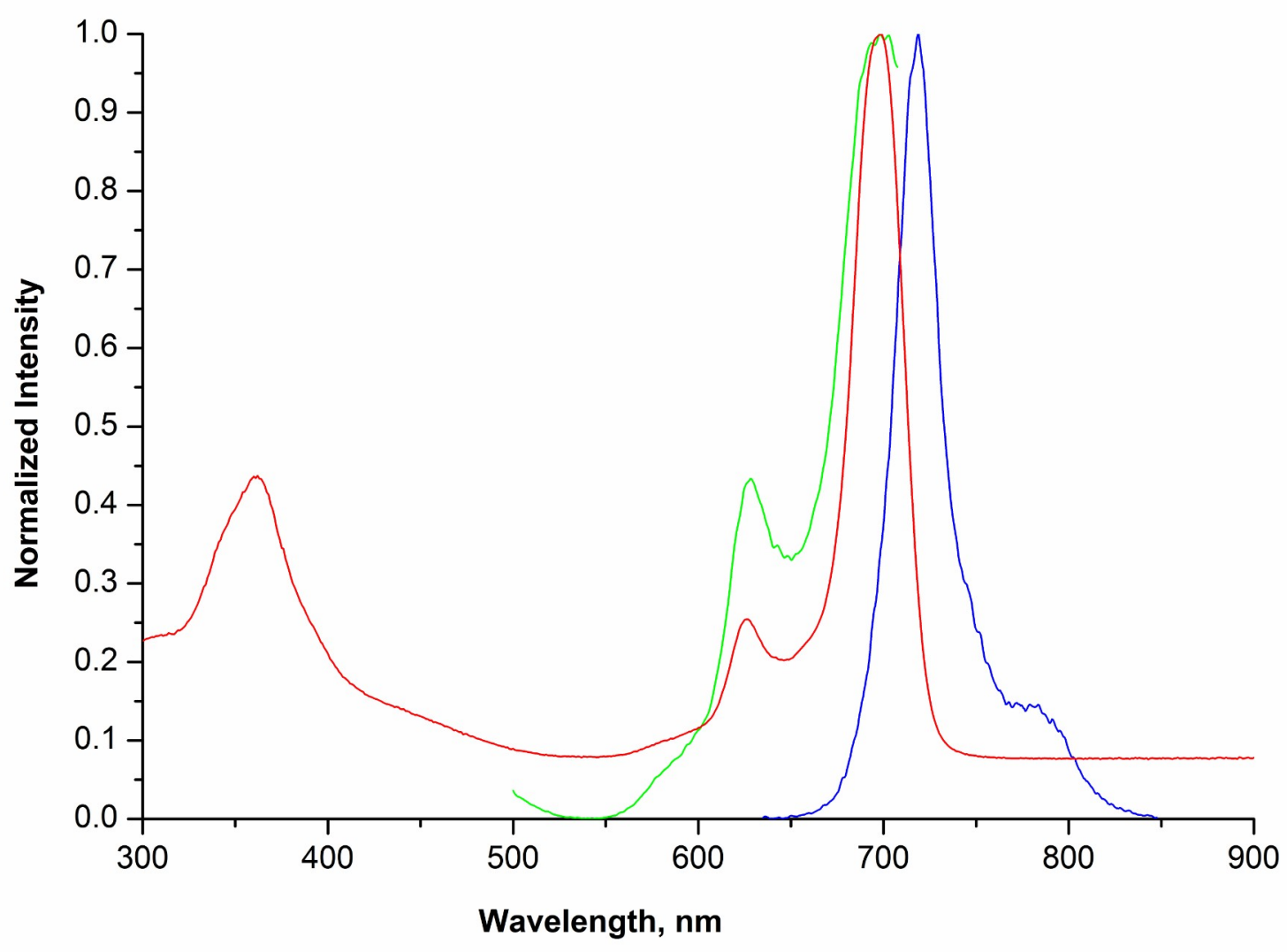

Figure 1: Absorption (red), excitation (blue) and emission (green) spectra of 3 in THF $\left(4 \times 10^{-6} \mathrm{M}\right)$.

The fluorescence quantum yield $\left(\Phi_{F}\right)$ of unsubstituted $\mathrm{ZnPc}$ is 0.17 in DMF and was used as a reference in calculating the $\Phi_{\mathrm{F}}$ value of compound 3. The $\Phi_{F}$ value of $\mathbf{3}$ in the THF has been determined as 0.21 , and this value is greater than the $\Phi_{F}$ value of the reference $\operatorname{ZnPc}(30,31,42)$. According to the literature, Dinçer and coworkers synthesized symmetric and unsymmetric Pcs bearing dipentoxymalonyl, chloro, and hexylthio units. They studied their photophysical properties and reported that the unsymmetric $P C\left(\Phi_{\mathrm{F}}=0.13\right)$ exhibited a greater fluorescence quantum yield in
$\mathrm{CHCl}_{3}$ than the symmetric analog $\left(\Phi_{\mathrm{F}}=0.072\right)(12)$. In this study, the fluorescence quantum yield of morpholine substituted unsymmetric Pc (3) was found to be greater than the value of the symmetric and unsymmetric derivatives in the literature (12).

The natural radiation life $\left(T_{0}\right)$ and fluorescence life $\left(T_{F}\right)$ of compound 3 were determined as 6.34 ns and $1.33 \mathrm{~ns}$, respectively. When the calculated values were compared with the values of the unsubstituted $\mathrm{ZnPc}\left(\mathrm{T}_{0}=6.05, \mathrm{k}_{\mathrm{F}}=1.03 \mathrm{~ns}\right.$ ), it was found that compound 3 have higher $\mathrm{T}_{0}$ and $\mathrm{k}_{\mathrm{F}}$ values $(30,31)$. 


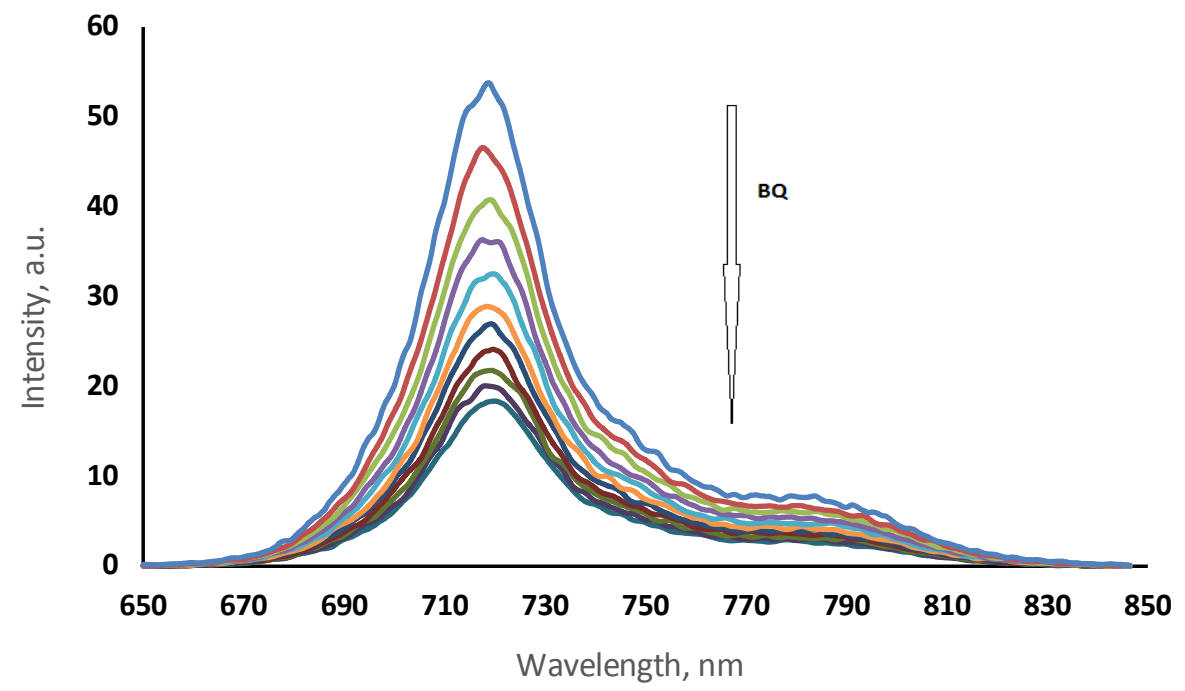

Figure 2: Fluorescent emission spectral changes of $3\left(4 \times 10^{-6} \mathrm{M}\right)$ in THF in which different concentrations of hydroquinone in THF was added as quencher. [BQ] $=0.000,0.008,0.016,0.024,0.032,0.040 \mathrm{M}$.

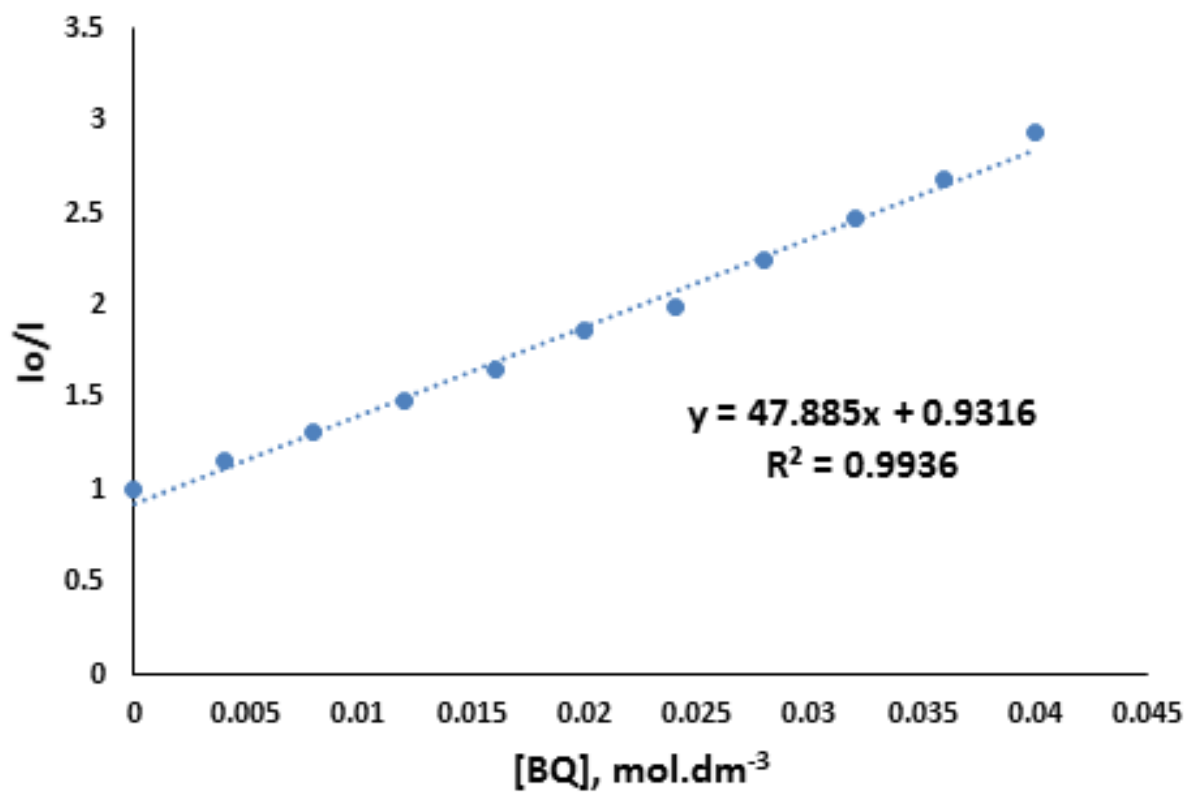

Figure 3: Stern-Volmer plot of 3 for $B Q([B Q]=0.000,0.008,0.016,0.024,0.032,0.040 \mathrm{M})$.

Fluorescent quenching studies of compound $\mathbf{3}$ were done by adding benzoquinone at different concentrations in THF, and it was observed that it complied with Stren-Volmer kinetics. The emission plots recorded after adding different concentrations of $\mathrm{BQ}$ to compound $\mathbf{3}$ are given in Figure 2 . As the concentration of the $\mathrm{BQ}$ increases, the intensity of the emission peak appears to decrease. In addition, as seen in Figure 3, as a result of the diffusioncontrolled quenching mechanism, the slope is linear, and the $\mathrm{K}_{\mathrm{sv}}$ value was calculated as $47.89 \mathrm{M}^{-1}$ (32, 33). kq (bimolecular quenching constant) value of compound 3 was calculated as $3.60 \times 10^{10} \mathrm{~s}^{-1}$. The $\mathrm{K}_{\mathrm{sv}}$ and $\mathrm{K}_{\mathrm{q}}$ values of compound $\mathbf{3}$ are smaller than the reference unsubstituted $\mathrm{ZnPc}\left(\mathrm{K}_{s v}=57.60 \mathrm{M}^{-1}\right.$, $\mathrm{k}_{q}=5.59 \times 10^{10} \mathrm{~s}^{-1}$ ).

\section{CONCLUSION}

It is reported from studies in the literature that morpholine groups positively change the biological activity of phthalocyanines. In addition, due to the electron donor feature of the sulfur atom, the hexylthio groups shift the $Q$ band of phthalocyanines to the near IR region. Therefore, the synthesis of zinc phthalocyanine carrying hexylthio and morpholinoethoxy groups was thought to be a suitable candidate for biological applications. In this study, a novel peripherally substituted unsymmetric $\mathrm{ZnPc}$ (3) containing six hexylthio units, and a morpholine group was synthesized. The compound's characterization was successfully performed using various spectroscopic methods and 
supported the accuracy of the proposed structure. Photophysical measurements of $\mathbf{3}$ were examined in THF. The fluorescence quantum yield and fluorescence lifetime for $\mathbf{3}$ were calculated and compared with the unsubstituted reference $\mathrm{ZnPc}$, and octakis hexylthio substituted $\mathrm{ZnPc}$ and found to be greater than both unsubstituted and octasubstituted ZnPcs. Fluorescence quenching studies for compound $\mathbf{3}$ were performed in THF and with the addition of various concentrations of $\mathrm{BQ}$. $\mathrm{K}_{s v}$ and $\mathrm{kq}$ values were calculated as a result of the fluorescence quenching studies. In comparison with unsubstituted zinc phthalocyanine, compound $\mathbf{3}$ showed lower $\mathrm{Ksv}$ and $\mathrm{kq}$ values. Compound $\mathbf{3}$ is a good candidate for biological applications due to its absorption in the near IR region and its higher fluorescence quantum yield than its derivatives in the literature.

\section{ACKNOWLEDGMENTS}

This work was supported by the Research Fund of the Istanbul Technical University.

\section{REFERENCES}

1. Hanack M, Schneider T, Barthel M, Shirk JS, Flom $S R$, Pong RGS. Indium phthalocyanines and naphthalocyanines for optical limiting. Coord Chem Rev. 2001;219:235-58.

2. Idowu $M$, Loewenstein $T$, Hastall $A$, Nyokong $T$, Schlettwein D. Photoelectrochemical properties of electrodeposited ZnO thin films sensitized by octacarboxymetallophthalocyanine derivatives. J Porphyr Phthalocyanines 2010;14:142-9.

3. Staicu A, Pascu A, Nuta A, Sorescu A, Raditoiu V, Pascu ML. Studies about phthalocyanine photosensitizers to be used in photodynamic therapy. Rom Rep Phys. 2013;65: 1032-51.

4. Jia X. Yang, FF, Li J, Liu JY, Xue JP. Synthesis and in vitro photodynamic activity of oligomeric ethylene glycol - quinoline substituted zinc(II) phthalocyanine derivatives. J Med Chem. 2013;56: 5797-805.

5. Ranyuk E, Cauchon N, Klarskov K, Gue B, van Lier JE. Phthalocyanine-peptide conjugates: receptor-targeting bifunctional agents for imaging and photodynamic therapy. J Med Chem. 2013; $56: 1520-34$.

6. Li $X$, Zheng BD, Peng $X H$, Li SZ, Ying JW, Zhao $Y$, Huang JD, Yoon J. Phthalocyanines as medicinal photosensitizers: Developments in the last five years. Coord Chem Rev. 2019; 379:147-60.

7. Zhao Y, Ying JW, Sun Q, Ke MR, Zheng BY, Huang JD. A novel silicon(IV) phthalocyanineoligopeptide conjugate as a highly efficient photosensitizer for photodynamic antimicrobial therapy. Dye Pigment. 2020;172:107834, 1-8.

8. Korkmaz E, Ahmetali E, Atmaca GY, Karaoğlu HP, Erdoğmuş A, Koçak MB. Investigation of photophysical and photochemical properties of phthalocyanines bearing fluorinated groups. Monatshefte für Chemie. 2020;151:181-90.

9. Yenilmez HY, Sevim AM, Bayır ZA. Synthesis and photophysics of new metallo phthalocyanine complexes with thiazole groups and their fluorescence quenching studies with benzoquinone. Synthetic Metals. 2013;176:11- 7.

10. Özçeşmeci M, Baş SS, Akkurt B, Hamuryudan E, Bolkent Ş. Synthesis and Biological Uses of A3B Type Water-Soluble Phthalocyanine Alternate to Alcian Blue. ChemistrySelect. 2018;3,12805- 12.

11. Uslan C, İşleyen ND, Öztürk Y, Yıldız BT, Çakar ZP, Göksel M, Durmus M, Gürsel YH, Sesalan BŞ. A novel of PEG-conjugated phthalocyanine and evaluation of its photocytotoxicity and antibacterial properties for photodynamic therapy. J. Porphyrins Phthalocyanines. 2018;22:10-24.

12. Uğur $A L$, Dinçer HA, Erdoğmuş A. Synthesis, photophysical and thermal studies of symmetrical and unsymmetrical zinc phthalocyanines. Polyhedron. 2012;31:431-7.

13. Sakamoto K, Sakaguchi Y, Watabiki S, Igarashi $Y$, Komoriya T, Yoshino S. Synthesis of phthalocyanines having thio-alkyl substituents at non-peripheral positions and their photochemical and photophysical properties. J. Med. Chem. Sci. 2019;2:64-70.

14. Chen SX, Du SY, Wang YT, Zhao HC, Zhang YL, Yao L. Retinoic acid morpholine amide (RAMA) inhibits expression of Fas ligand through EP1 receptor in colon cancer cells. Tumor Biol. 2016; 37:323-9.

15. Pal'chikov VA. Morpholines. Synthesis and Biological Activity. Russian Journal of Organic Chemistry, 2013;49(6):787-814.

16. Poupin $\mathrm{P}$, Mazure $\mathrm{N}$, Truffaut N. Morpholine degradation by strain Mycobacterium aurum MOI : improvement of cells growth and morpholine degradation rate by cells immobilization. in $\mathrm{R} . \mathrm{H}$. Wijffels, R.M. Buitelaar, C. Bucke and J. Tramper (Eds) Immobilized Cells: Basics and Applications, Elsevier Science B.V; 1996.

17. Jachak GR, Ramesh R, Sant DG, Jorwekar SU, Jadhav MR, Tupe SG, Deshpande MV, Reddy DS. Silicon Incorporated Morpholine Antifungals: Design, Synthesis, and Biological Evaluation. ACS Med. Chem. Lett. 2015;6:1111-6. 
18. Zhu $Y J$, Huang JD, Jiang $X J$, Sun JC. Novel silicon phthalocyanines axially modified by morpholine: synthesis, complexation with serum protein and in vitro photodynamic activity. Inorg Chem Commun. 2006;9:473-7.

19. Nene LC, Managa M, Nyokong T. Photophysicochemical properties and in vitro photodynamic therapy activity of morpholinesubstituted Zinc(II)-Phthalocyanines $\Pi-\Pi$ stacked on biotinylated graphene quantum dots. Dye Pigment. 2019;165:488-98.

20. Sindelo A, Kobayashi N, Kimura M, Nyokong T. Physicochemical and photodynamic antimicrobial chemotherapy activity of morpholine-substituted phthalocyanines: Effect of point of substitution and central metal. J Photochem Photobio A: Chemistry. 2019;374:58-67.

21. Dlugaszewska J, Szczolko W, Koczorowski T, Skupin-Mrugalska $P$, Teubert A, Konopka $K$, Kucinska $M$, Murias $M$, Düzgüneş $N$, Mielcarek J, Goslinski T. Antimicrobial and anticancer photodynamic activity of a phthalocyanine photosensitizer with $\mathrm{N}$-methyl morpholiniumethoxy substituents in nonperipheral positions. J Inorg Biochem. 2017;172:67-79.

22. Kucinska $M$, Skupin-Mrugalska $P$, Szczolko $W$, Sobotta L, Sciepura M, Tykarska E, Wierzchowski M, Teubert A, Fedoruk-Wyszomirska A, Wyszko $E$, Gdaniec M, Kaczmarek M, Goslinski T, Mielcarek J, Muria M. Phthalocyanine derivatives possessing 2-(morpholin-4-yl)ethoxy groups as potential agents for photodynamic therapy. J Med Chem. $2015 ; 58: 2240-55$.

23. Zheng BY, Lin $\mathrm{T}$, Yang $\mathrm{HH}$, Huang JD. Photodynamic inactivation of Candida albicans sensitized by a series of novel axially di-substituted silicon (IV) phthalocyanines. Dye Pigment. 2013;96:547-53.

24. Barut B, Demirbaş Ü, Şenocak A, Özel A, Kantekin $H$. Water soluble axially morpholine disubstituted silicon phthalocyanines: Synthesis, characterisation, DNA/BSA binding, DNA photocleavage properties. Synth Met. 2017;229:2232.

25. Biyiklioglu Z. Electrochemical and aggregation properties of newly synthesized dendritic axially morpholine-disubstituted silicon phthalocyanine, mono-substituted subphthalocyanine and their quaternized derivatives. Inorg Chem Commun. 2015;55:60-4.

26. Burat AK, Koca A, Lewtak JP, Gryko DT. Synthesis, physicochemical properties and electrochemistry of morpholine-substituted phthalocyanines. J Porphyr Phthalocyanines. 2010;14:605-14.

27. Burat AK, Koca A, Lewtak JP, Gryko DT. Preparation, electrochemistry and optical properties of unsymmetrical phthalocyanines bearing morpholine and tert-butylphenoxy substituents. Synth Met. 2011,161:1537-45.

28. Gurek AG, Bekaroglu O. Octakis (alkylthio)substituted phthalocyanines and their interactions with silver (I) and palladium (II) ions. J Chem Soc Dalton Trans. 1994;1419-23.

29. Koçan H, Kaya K, Özçeşmeci İ, Sesalan BŞ, Göksel $M$, Durmuş $M$, Burat AK. Photophysicochemical, calf thymus DNA binding and in vitro photocytotoxicity properties of tetra-morpholinoethoxy-substituted phthalocyanines and their water-soluble quaternized derivatives. J Biol Inorg Chem 2017;22:1251-66.

30. Karaoğlu HRP, Yenilmez HY, Koçak MB. Phthalocyanines formed from several precursors: synthesis, characterization, and comparative fluorescence and quinone quenching. Journal of Coordination Chemistry. 2018;71(15):2340-57.

31. Zorlu Y, Dumoulin F, Durmuş $M$, Ahsen V. Comparative studies of photophysical and photochemical properties of solketal substituted platinum (II) and zinc (II) phthalocyanine sets. Tetrahedron. 2010; 66(17):3248-58.

32. Du H, Fuh RCA, Li J, Corkan LA, Lindsey JS. PhotochemCAD: A Computer-Aided Design and Research Tool in Photochemistry. Photochem. Photobiol. 1998;68:141-2.

33. Rose J. Advanced Physico-chemical Experiments, first ed., Sir Isaac Pitman \& Sons Ltd., London; 1964, p.257.

34. Leznoff CC, Hall TW. The synthesis of a soluble, unsymmetrical phthalocyanine on a polymer support. Tetrahedron Lett. 1982;23:3023-6.

35. Erdem SS, Nesterova IV, Soper SA, Hammer RP. Solid-phase synthesis of asymmetrically substituted "AB3-type" phthalocyanines. J Org Chem. 2008;73:5003-7.

36. Kobayashi N, Kondo R, Nakajima S, Osa T. New route to unsymmetrical phthalocyanine analogs by the use of structurally distorted subphthalocyanines. J Am Chem Soc. 1990;112:9640-1.

37. Kobayashi $\mathrm{N}$, Ishizaki $\mathrm{T}$, Ishii $\mathrm{K}$, Konami $\mathrm{H}$. Synthesis, spectroscopy, and molecular orbital calculations of subazaporphyrins, subphthalocyanines, subnaphthalocyanines, and 
compounds derived therefrom by ring expansion. J Am Chem Soc. 1999:121;9096-110.

38. Kalkan A, Koca A, Bayır ZA. Unsymmetrical phthalocyanines with alkynyl substituents. Polyhedron. 2004;23:3155-62.

39. Haas M, Liu SX, Kahnt A, Leiggener C, Guldi DM, Hauser $A$, Decurtins $S$. Photoinduced energy transfer processes within dyads of metallophthalocyanines compactly fused to a ruthenium(II) polypyridine chromophore. J Org Chem. 2007;72:7533-43.

40. Kimura T, Kanota N, Matsui K, Tanaka I, Tsuboi
T, Takaguchi Y, Yomogita A, Wakahara T, Kuwahara S, Nagatsugi F, Akasaka T. Preparation and electrochemical and optical properties of unsymmetrically substituted phthalocyanines with one or two trithiole rings and related symmetric derivatives. Inorg Chem. 2008;47:3577-83.

41. Özçeşmeci M, Nar I, Hamuryudan E. Synthesis and electrochemical and spectroelectrochemical characterization of chloromanganese(III) phthalocyanines. Turk. J. Chem. 2014;38:1064-72.

42. McKeown NB, Li $\mathrm{H}$, Helliwell M, J. Porphyr. Phthalocyanines. A non-planar, hexadecasubstituted, metal-free phthalocyanine. 2005;9(12):841-5. 
